\title{
URBAN DYNAMIC IN SPACES OF CRISIS: PORT PRINCE/HAITI
}

\author{
dinâmica urbana de espaços em crise: Porto Príncipe/Haiti
}

Adriano Bittencourt Andrade *

\begin{abstract}
Resumo
Esse artigo aborda as diversas facetas de crises que se espacializam no meio urbano. O texto desse artigo, à luz da dinâmica que rege o espaço geográfico, se debruça sobre as crises urbanas e lança um olhar focal sobre o caso do Haiti, avaliando as repercussões das crises que se entrecruzam (crise política, luta armada, intervenção externa, bruscos fenômenos naturais - terremoto e furacões -, dentre outros) no espaço urbano de Porto Príncipe, sua capital. Para a produção desse artigo, a pesquisa se desenvolveu em duas frentes: recorreu-se às fontes bibliográficas acerca do Haiti e da própria temática em foco; e fez-se entrevistas diretas com militares que participaram, representando o Exército Brasileiro, da Missão de Paz da ONU no Haiti. Analisa-se a relação entre a produção material do espaço e a sua ocupação e uso social, trazendo elementos para entender a profunda fragmentação que há na cidade gerando uma dinâmica interna absolutamente dicotômica entre uma pequena elite e a imensa população que vive em espaços de exceção. Mais que apresentar uma miríade de informações e dados sobre o paupérrimo país antilhano, esse artigo, a partir de uma realidade concreta, lança "flechas" interpretativas sustentado na análise da configuração territorial e, assim, estimula o debate que, para além da perspectiva local, tende a encontrar reflexo em vários outros lugares do mundo.
\end{abstract}

Palavras-chave: Crise. Espaço urbano. Haiti. Porto Príncipe. MINUSTAH.

\begin{abstract}
This paper addresses the different facets of the crisis that take place in the Urban space. The discussing of this article, considering the dynamics that leads the geographical area, focus its attention on urban crisis and puts its eyes on Haiti case. Evaluating the repercussions of the crisis that interwoven themselves (political crisis, armed struggle, external intervention, sudden natural disasters - earthquakes and hurricanes) in the Urban space of Port Prince, its capital. In order to produce this paper the research was conducted in two ways: consulted the bibliographical resources on Haiti and on the theme on focus itself; and it was done direct interviews with militaries that took part, representing Brazilian Army, in the United Nations Mission in Haiti. This article analyses the relation between documental production of the space and its occupation and social use, bringing elements to understand the deep fragmentation that exist in the city, which generates a internal dynamics completely dichotomous between the small elite and the huge population that lives in places of exception. More than present a myriad of information and data about the very poor Antillean country, this paper, considering a concrete reality, suggests some nuances of interpretations based on the analysis of the territorial configuration, and, thus, encourages discussions that, beyond the local perspective, try to find out a reflect in many other places in the world.
\end{abstract}

Key words: Crisis. Urban Space. Haiti. Port Prince. MINUSTAH.

\begin{abstract}
Resumen
Este artículo aborda las diversas facetas de la crisis que se materializó en el espacio urbano. El texto de este artículo, a la luz de las dinámicas que rigen el espacio geográfico, se centra en las crisis urbanas y echa un vistazo al caso focal de Haití, evaluar el impacto de las crisis que se cruzan (crisis política, los conflictos armados, la intervención externa, los desastres naturales repentinos - terremotos y huracanes - entre otros) en el área urbana de Puerto Príncipe, la capital. Para la producción de este artículo, la investigación se ha desarrollado en dos frentes: se recurrió a las fuentes bibliográficas sobre Haití y su propio enfoque temático; y hubo entrevistas directas con los soldados que tomaron parte, en representación del Ejército de Brasil, la Misión de Mantenimiento de la Paz de la ONU en Haití. Este artículo análisis la relación entre la producción de material de espacio y su ocupación y uso social de proporcionar elementos para comprender la profunda fragmentación que hay en la ciudad generando un absolutamente dicotómicas dinámica interna entre una élite y la gran población que vive en los espacios de excepción. En lugar de presentar una gran cantidad de información y datos sobre el empobrecido país antillano, en este artículo, a partir de una realidad concreta, lanza "flechas" de interpretaciones sostenidas en el análisis de la configuración territorial y por lo tanto estimula el debate, más allá de la perspectiva local tiende a reflejarse en muchos otros lugares del mundo.
\end{abstract}

Palabras Clave: Crisis; Espacio urbano; Haití; Puerto Príncipe; MINUSTAH.-

(*) Phd, Geography teacher at Military School of Brasilia - SGAN 902/904 Asa Norte Zip Code:70790-020 Brasília (DF), Brazil. Tel: (+55 61) 3424-1001 - abittandrade@gmail.com 


\section{INTRODUCTION}

Haiti is showed for us by the Midia under two perspectives: or as more one of the touristic destination in the caribien landscape or as a "country example" of the worst socio economics indacators of the world. More recently, precisely in the last decades, as a result of internal conflicts by the power sucession and violent natural events, the second case has shaded the first.

The reality of poverty and exclusion, especially to the ones who live in big cities of the peripheral countries (but also in guettos of the central countries) is presented in the daily view, what is called by Davis (2006) "planet slum".

It is possible to verify the segregaded spaces, of low income, with terrible infrastrutural conditions in many places of the world, however, nothing seems to be so shoking as the concrete life that occurs in the main city and capital of Haiti: Port Prince.

If our contemporaneity is printed by crisis and they are set, fundamentally, in the urban space, it seems to us that in Haiti there is a vectorization of more than one constraints of the crisis of our times producing an organization and territorial dynamic completely peculiar and cruel.

That is to say, it is in this scenary of crises that has a global reach, since it impacts differently and with major or little intensity in all the countries, that emerged the stimulus to think on the dinamic of one urban space that represents in the global imaginary (by the media) the lack and exclusion, the conflicts and the crisis itself.

It aims, so, in the text of this article, which has as a focus the organization of the geographical space, analyze the territorial dynamics of Haiti, notably of its capital, Port Prince, in a context in which varied instances of the problems "touch" in a place (political crise, armed struggle, external intervention, abrupt natural phenomena, - earthquake and hurricaines -, among others).

Understanding the space as a totality, and considering Lefebve's idea (1979), it is inteded, at the end, unveil how life is happening is the concrete sphere of the haitian citzens in their daily routine in Port Prince. How the relations between the Global and Local change it in a concrete space and the strategies of the subversion of the various crisis that take that country.

In order to organize this text, besides a bibliographical research, it was fundamental the development of the interview with representatives, in many levels, of the Braziliam Army that participated in the UM Peace Mission in Haiti. As a result of this rich primary colect product, this writing is structured that follows in two sections: (1) On contemporaneity of crisis, in which it is intended to situate space-temporally the context of crisis of our times. (2) The territorialization of the crise in Hait: the empirical reading of the banal, in which a preliminary evaluation of the territorial organization and the most recent historical events is developed (especially after the ocupation of the country by the MINUSTAH, United Nation Stabilization Mission in Haiti, peace forces), a fundamental strategy to understand the region before the analisis of the processes that take place in the capital of the country; This second section is fragmented in two subsections: (2.1) Ocupation and use of the territory in our contemporaneity: the presence of UN and (2.2) General markings of the territorial configuration of Haiti, in which is done a brief historicizing of the territorial relations in the caribean, since its Independence up to, and especially, the beginning of the XXI century with the ostensive presence of the UN peace forces, it is also intended to present the elements of the territorial configuration of the main city of Haiti, evaluating critically the relation between the material production of the space and its occupation and social use, bringging the elements to understand the deep fragmentation that exists in the city, generating a internal dynamics absolutely dichotomous between a small elite and the huge population that lives in spaces of excession.

In this text, limited by the dimension of an article an by the brief field research, it is intended to presente to the discussion subthemes as the importance of donations and funds outflows to the peripherals spaces (on the other hand, the youth emigrants evasion); the roles of the NGOs in the assistentialism and/or the expediency before a deep exclusion; ills of funds that, even in cenarios of intense crisis, find ways to reproduce themselves (local markets and fairs to the high income 
population, selling of "imported stuffs", tourism - product: Caribean sea - services, internal production, supplies and infrastructure to the two economics circuits - superior and inferior (SANTOS,1979) - of a segregated city).

Thus, as a remark, in advance, it is not intended to presente a myriad of information and data on the poorest Antillean country, but from its concrete reality send interpretative "arrows" based on the analise of the territorial configuration and, in this sense, estimulate the debate that, far from the local perspective, has the tendence to find the reflect here and in many other places of the world.

\section{A CONTEMPORANEITY IN CRISIS}

Formation of traffic territories in Rio de Janeiro that confront the "local power", more than $60 \%$ of subnormal houses (with some kind of needs or legalities - housing housing deficit qualitative) in Salvador Salvador (ANDRADE; BRANDÃO, 2009), gangs formation of unemployed youths in Lisbon; suffering of pos adolescents' parentes in small cities of USA due to the fact of the lack of job opportunities; expansion of the number of policemen homicides in São Paulo (with numbers of death similar to the war areas); shocks between opposing forces in Cairo; extension of xenophobic moviments in German and French cities; continuous fear of terrorist atacks in Jerusalem; Strong restrictions to the individual freedom in Nanking; lack of infrastructures of all kinds in cities as Kabul and Port Prince; reports of corruptions schemes in public organisms in Brasília.

Those pieces of information have something in common. They are problems that take place in cities.

The world became urban! Considering the immense diversity of what we call urban (including the variation on the methodology among the countries), it is a fact that the major part of the mosto $\mathrm{f}$ seven billions of human live in agglomerations that reach millions of people. That demographical gathering, due to the shock of interests, is a inevitable space of conflicts. As said by Tuan (2005, p.251): "a city [... is] a complex society of heterogeneous people living close to each other. [...] the heterogeneity is also a condition that incentive the conflict".

The city that, originally, was a space for protection against barbarism and the public living, turn into also a space of tensions and fear. Marcelo Lopes de Souza (2006) reminds us of this dicotomy in the titlle of his book: "The Prison and the Agora. The space in which the humans live is also their prison. In the cities, especially the big ones, we live imprisoned in our castles (rooms, houses, cars, offices, condos, parks and private clubs, and so on...), "protected" from the other, minimizing the possibilities of living with the different. Souza (2006, p.20) insists that "which predominates, which prevails is the fear - always an enemy of freedom. In what are turning so many and many big cities of today, converted in real 'fobópoles' (gr. phobos = fear).

This thought-provoking issue points out to a clear idea in which we live in "sick" urban spaces. We live in crise! In this sense, Topalob (1991) remind us that the "crise" was always present since it was thought in rationalize the urban space, in other words, althought the use of the same terminology, the composition of the variables and specificities produced over the last centuries "several" urban crisis. The contemporaneity does not run from this ritual.

It can be affirmed that it is a crise of the urban confronting with the greek matrix (HABERMAS, 1984), as well as a diversity of the crisis in the cities; the peculiarities that mark each place define the dimension, the characteristics and the ways of facing the problems here, there and yonder spacialize themselves.

It is about this city in crise that Ermínia Maricato discusses in order to present fundamental issues of difficult facing:

what it can be done with the illegal and violent city? And with the fragile environmental areas, occupied by the poor housing? Which could be the solutions, in a short and a médium term to the tragedies caused by floods, landslides, fires and epidemics? How to face the real state highly speculative and 
excluding? How to combine the occupation of the urban soil and the road system with the units of manegement based on hydrographic and sub hydrographic basins? How to implemente the social role of the property? How to do, objectively, the control of the use of the soil (one of the most corrupt sectors of the municipal managements) protecting the fragile environmental areas and assuring the expansion of the offers of social housings? How to convince the society and the governos of the priorities needed by the problems of drainage and sanitation? What to do with the informal trading that occupies the public spaces? How to garante some minimum patterns of habitability in already urbanized slums? What are those minimum patterns to a housing confort, road and pedestrian circulation scheme, the public areas, the garbage removal, the sanitation and its maintenance? How to promote the social engagement to the resolution of the problems that exceed the partícula claims? (MARICATO, 2001, p.49).

Certainly those mentioned questions by Maricato reflects in many cities around the world, especially in an urban site of peripheral countries in which the ills of fund fragmente still more abruptly the spaces producing reveiling landscapes of urban segregation and exclusion.

Leading with a great number of problems in the peripheral cities of Latim America, Kovarik (1979) denaturalizes the crisis, stating that in truth there is not a disorder, but a logical perverse in the organization of the social space that produces as a result, but also as an ongoing dynamics process, the urban spoliation.

Maybe the most perverse side of this plundered space might be the dehumanisation of the relations (SANTOS, 2000, p.46 e 85). A homeless person, a beggar at the traffic ligh, a passer-by who feels bad or news on a homicides and another barbaric acts, touch us just the time of the next horn or the following concern in the stubling and insensitive live in the big cities.

The german sociologist Georg Simmel, in the beginning of the XX century, teaches that it is fundamental to understand this untying of the sentimentalities of the urban social relations, relate it to the economics domain which envolves it. Still, that

the rationality of the phenomenum is not commensurable as a pecuniary principle. Money refers only to what is common to everything: he asks for the exchange value, reduces all the quality and the individuality to the question: how much? All the intimate emotional relations among people are founded in the rational relations, it is worked with the man as a number, as an element which is in itself even indifferent. Only the objective achievement, measurable is of interest. (SIMMEL, 1976, p.13).

The logic of the capital that involves and absorves all the relations in those major cities, generating its own attractiveness as a knot of diverse networks in many scales, also determines the relations among men that live there, not "allowing" sentimentality and a level of involviment that are not compatible with the money domain. The author even deals with anonimous relations which take place in this space. In this sense we can update with examples of "virtual sex" and "marriage through internet". This theme also stimulates the debate on the citzen invisibility in the public space that in the past configurated itself, according to Habermas (1984), as a space of the invisibility and the political relation among the inhabitants and, at the modern times (since Simmel, the end of the XIX century) is engulfed by a social sphere that bounds the individualities to restricted spaces, changing public spaces into group space. Which do a beggar ou an abandoned child mean, besides a "risk", to the population in a hurry in a busy street of a major city?

According to Simmel (1976, p.16), the rationality of the money "turn itself the common ruller of all the values: takes irreparably the essence of everything, its individuality, its specific value and its incomparability".

Leading with his life experience and its Works as antropologist and urban sociologist, the "paulista" Flávio Pierucci (2003) studies the city as a field of the physical union of the diferences, or at least the evidence of those differences. Racism, xenofobic movements, social segregation (attemp) are daily examples, in a great number of scales, these experiences of social contacts among the different in the urban setting. The author brings back Simmel to lead with the urban way of life where 
there is a great physical approximation, but without social involvement. The belief of the invisibility in the crownd. Pierucci affirms that the indifference to the other only takes place where there is not the conflict in the territorial relation. On the other hand, if the territorial domains (habits, beliefs, spaces, and soo n.) is questioned the tension is instaured and the "blame" rests upon the different, the other one. If the differences that originated the crisis are in the individual values sphere or of the groups, the problems get worse, because it does not have a pacific term among different values.

In other words, it is not possible to detach the diverse crises scenary that we face and annouce to the capitalist system that reaches its more advanced phase fulfiling globally by the extension of the production and consumption and, mainly, by the omnipresence of the financial capital (ANDRADE, 2010). The human being is brutalized and its role as a citzen gives place to the consumer (SANTOS, 2000, p.49). An ideal context for the explosion of all kind of conflicts, notedly in spaces of great demographic density in where according to Pierucci (2003), get in shock territorial interests of individuals or groups.

\section{THE TERRITORIALIZATION OF THE CRISIS IN HAITI : EMPIRICAL READING OF THE TRIVIAL SPACE}

The debate on the crisis, ver the risk of became rhetorical, needs of the folding down in the territory. In this sense, it is evaluated through this section, the concrete case of the crisis established in Haiti, notedly, in its capital and in its main urban center, Port Prince.

In a brief exercise of retrospective, it is possible to check in the recente history of Haiti, a series of nuances that sinalizes the current condition of the Caribbean country (JAMES, 2010, p.362-363).

Haiti conquered its political independence in 1804, become itself into the first nation coming from a revolution begotten by black slaves. The continuity of conflicts, the lack of economic support from the european nations and from the USA in the pos Independence, the disturbed transition from the sugar cane plantation (based on the slavery) to a livelihood (JAMES, 2012, p.346) had a catastrophic effect a medium term makind that, at the end of the XIX century, Haiti was under the strong influence that the United States of America had (and, in large scale, they are still exerting) along with the caribbean countries .

Forming this way a perverse scenario in which a small local elite, aligned with the international interests, organized and used the territory on the role of the external demands. The "order"was kept from the force and the establisment of on competent speech that justified of such use.

Cyril James (2010, p. 359), clarifies this dichotomous reality presente in the Caribbean countries when affirms that

as well it had been since the first days of slavery, the financial power and its mechanism are today entirely controlled by the major cities and their agentes. A population so westernized needs certain goods, such as jugs, pots, plates, spoons, knives, paper, pencils, pens, fabric, bicycles, buses for public transportation, automobiles and all the basic elements of the civilization, which are not produced in the islands, without forgetting of the mercedes-benzs, of the Bentleys, of the Jaguars, and of the Lincolns. In this type of commerce, the dominant elements are the producers and the foreign banks. The most revealing and also most ancient characteristics of this commerce is still the bulk import of food, including fresh vegetables. Few industries of importance such as oil and bauxite are totally in the hands of the foreign companies; and the local politicians lead the fierce competition among themselves to offer incentives to similar companies aiming that they set new industries here and not in any other place.

The current contexto of extreme crisis can not be understood without this brief evaluation of the historical course and the understanding of the last political succesions since the middle of the XX century.

Summarily, according informations in Williams (1984), Eakin (2007), James (2010) e ONU (23 mar 2014), it is possible to affirm that the temerarious socioeconomic situation and the univo- 
cal fragile of the political institutions and of the State itself (Forces of protection - military and police- judiciary, and so on.) are straight result of a sequence of governos that succeed in the power asserting a right of personal rights or of small groups, what Williams (1984, p.509) calls "mulatto elite", and this way creating a absolutely fragmented and unequal space, fruitful field for the deep crises that the haitian territory faces in the rising of the XXI century.

Allied with old and pernicious bonds between a small national elite and international groups of interests in the use of the hatian territory, the dictatorships of the XX century left indelible marks in the recent history of the country.

In 1957, François Duvalier (Papa Doc), was elected presindent and immediately imposed a totalitarian regime supported in the Tontons Macoutes force (defense force of his political group) and of the strong repression to any antagonistic idea to his violations. Up to his death, in 1971 and after with the permanence of his son(Jean - Claude - Baby Doc) in the power until 1986, when he was put in exile, they were 29 years of political control, spoliation of the most basic social conditions and the extreme use of internal resources aiming to benefit small groups and the international companies.

The arrival of Jean-Bertrand Aristide to the power and the achievement of the free elections in 1990 did not tranquilize the turbulance of internal policitcs. Aristides was militarily deposed in 1991, beginning a new political and economics representative crisis (in big scale due to the strong sactions that was suffering internationally). In 1994, under the auspices of the United States of America, Aristides is brought back to the power and manages to carry out a new election in 1996, when René Préval arrives to the power, staying there until 2001. In a new election, Aristides reassumes the presidence, however, with a strong internal conflict (many groups with the territorial domain in the country and in its main city), he was not able to arrive to the end of his mandate and he is put in exile in the beggining of 2004.

That was the scenario that determined the arrival of MINUSTAH (United Nations Mission for the Stabilization of Haiti): a strong political instability with the sight of a civilian war in an anarchic and brutal state with the hatian territory very fragmented by different political forces that controlled the population in a coercive form. The socioeconomics indexes (EAKIN 2007, p.367) revealed the extreme poverty that was taking the first independent country in the Latim America.

\section{OCCUPATION AND USE OF THE TERRITORY IN OUR CONTEMPORANEITY: THE UN PRESENCE IN HAITI}

by the first time in the History of Haiti, a democratically elected president - René Préval - ends his madate and, after national elections - not with challenges - handed the power to a opposed candidate (announced in April of 2011), the current presidente Michel (Joseph) Martelly, in a relatively peaceful way (ONU, 25jun2013).

This announcement in the official page of United Nation celebrates some of successful to the mission to the establishment of the Peace in Haiti. The presence of UN, in the recent history, is very much frequente in that territory. As informed by Donadío and Rial (2013, p.105), between 1993 and 1996 UNMIH was established; between 1996 and 1997 and, from 1997 to 2000, the MIPONUH.. However, after 204, with the establishment of MINUSTAH, following the Resolution 1542 by UN Security Council, he phases of prevention of the conflict and the Peace keeping were effectively reached. In this last decade, the history of Haiti and the presence of the UN forces has an umbreakable bond.

The Mission comes from the idea of acting with neutrality from the consensus of the legal representatives of the country, however it met, in 2004, a country completely areally fragmented and with a very few representative State, as it was reported in the mentioned interviews. There was the prerogative of, initially, building a safe and stable environment in order to the State could impose itself in a way that the gradual leaving of the UN forces could permit the autonomous conduction 
of the country by the Haitian State. In this sense, it started a strong presence of the military and a small civilian action with a tendence to invert of these different perspectives of intervention.

In general lines, it was found, in 2004, the cities under the command of the rebel forces and, with the establishment of the presence of MINUSTA, it was reached the minimum stabilization to the attainment of the presidential election, in 2006 (René Préval took the presidence). Between 2006 and 2007, the military control was take in Port Prince, capital and main urban nuclei in the country. In 2008, there were records of riots due to the high costs of living and in this same time three hurricaines reached the island and as a consequence there were the humanitarian aids. In 2010, when timetable of the military troops departures was being designed, a violent earthquake took place - intensity 7,0 in the Ritcher scale, but the epicentre was only $25 \mathrm{~km}$ of the capital - with an impressive balance of the destruction of the physical instructures (more than 1.500.000 displaced people) and the death of more than 250.000 haitians. From this point, besides the resumption of Peace (shaken by the destruction of facilities such as jails and the Judiciary documents) the perspective of leaving the country was linked to the material and institurional politics reconstruction of Haiti.

The observation of the variation of the number of military personnel, braziliam majority, ratifies the progress of the events in the last years, since the major numbers were always linked to moments of major tension: In 2010, before the earthquake, the number was 6.940 troops. After the earthquake, adding with a new unit created fundamentally to answer the demands of the catástrofe (BRABAT 2), the number jumped to 8.940. From that point on there was a continuous reduction of the number of the military personnel to 7.340, em 2012, and 6.270 in 2013. Confirming the perspective of the time of the MINUSTAH action increasing the political action and the human rights and reducing the presence of the militar and police components.

The data on the violence in Haiti are innacurate but terrifying, however, due to the UN military presence, it is believed that there is in Haiti less crime than in the majority of the Caribbean countries. So the problem is in difficulty of the transition of the ostensible presence of intervention and the establishment of a Rule of Law respected by all the internal groups.

The training and the increase of National Police of Haiti personnel, with the expectation of a total of 13.000 personnel up to the end of 2016, after the presidential elections, could mean the an encouragement to the Peace control, however, as told by Donadio and Rial (2013, p.153), "The National Civilian Police has 10.000 personnel and it does not have a suitable level of professionalism, and it does not have the trust of the population, and it is affected by constant coruptions pratices".

The corruption problem involves other spheres of the public power. There is an obvious difficulty in reach a democratic composition that keeps, minimally, the governability, due to a strong oposition among historically hostile groups.

The disruption and the workings of the Judiciary power are emblematic and exemplary to the understanding of the difficulties of the total autonomy of the country. Despite the recent advances, such as the installation of the courts in the countryside of the country, the quantity of judges and the working hours, is absolutely insufficient to judge the crimes processes, thus, there are a lot of prisoners waiting for the judgement, beyond to any expected parameter. Besides that, part of the formal documents (processes, petitions, files, libraries, and so on.) "desappear" in an brief time of the earquake of 2010. A truely institutional chaos to be recovered. A huge rework in a space in crisis with a deep deficit in the public action.

The lack of education, the nonexistence of the trash removal. The serious problem of sanitation, mainly in Port Prince (demographic aggregation, much bigger than the built infrainstructure capacity) complete the scenario of absolute poverty and absence of the State. The researchers Marcela Donadío and Juan Rial add affirming that

the state is sick, it is needed the truely control over all the territory, territorial Waters, air space. It is have a huge number of displaced people (369.000 in august of 2012, according to the OIM), as well as people living precariously, especially in the urban area. (DONADÍO e RIAL, 2013, p.106). 
As a risk of a tautological or partial discourse, it is added to the haitian crisis vectors the immense poverty that is emerged to the territory. Donadío and Rial (2013, p. 147) present upsetting data, based on counts of the last decades of the XX century, as a GDP per capita of 663 dolars per year, an income concentration absolutely perverse with a "high income class" $2 \%$ of the population that controls $44 \%$ of the GDP and a "middle class" of only $5 \%$ of the population, these two formed predominantly by immigrant people (north American, Arabic, and so on), characterizing also an ethinic nuance in the income distribution, with the poors formed by native black people.

In interview, General Goulart is emphatic when affirms that "Haiti does not have conditions by itself to overcome its socioeconomics problems", which is necessary an urgente joint action of police and politics aiming to reach the stabilization of peace and the construction of the institutional forces that make possible a bigger scope fo public actions with social purpose. This situation reveals a decisive realization of what Francisco de Oliveira (2003) called "social apartheid".

\section{GENERAL SIGNS OF THE TERRITORIAL CONFIGURATION OF HAITI}

MINUSTAH has its mandate covering the hatian territory as a whole (civil affairs component, logistic support, military and police component as well, are distributed in the country), as the problems in Port Prince are stronger, that is where the biggest number of personnel is placed as well as the concern on security, law and order operation, human rights, and the creation of the govern institutions.

From the reports of the interviews, it is possible to infer that, in the countrysides cities, the life quality is better, despite the major offers of services in the capital, the demographic growing and the lack of the sanitation make the dimension of the problems in the main urban nodal area is much superior to the capacity of answering the demand. The small cities are manageable, true villages of subsistence in rural activities, are much less big than in the capital and the problems easily controlled, even the one concerned to violence .

Marcelo José Lopes de Souza (2006, p. 29) is educational when affirms that "besides being a expression of the society (as contradictory as the own society that has produced it), the space, organized this way or that, is a requirement to what certains social relations can florish, be successfull", in other words, search for the peculiarities of the territorial configuration of Haiti, notedly of Port Prince, is an strategy to understand its own social dynamics in which takes place in that country.

In that search, some elements are highlighted, despite the diversity and complexity of the varied and unequal urban space that covers a large territory and takes into account with a populating of more than two millions inhabitants. In other words, the attemp of enlighten some aspects of the local territorial configuration means take the risk of absences and partiality of information in a very heterogenous space.

The fragmentation of the sociopolitical spatial land pointed by Souza (2006, Cap.11) as one of the perverse elements of the urban contemporaneityof the big cities in the peripheral countries, it also presents in Port Prince, however it comes wiht characteristics still more agressive, considering what was already mentioned, the social gap between the small elite and the huge number of urban poors.

Port Prince is the main way to enter and leave the country (maritime port and international airport) and in this urban group, as it is expected in an organized space by the logical of the capital, therefore all the values of the crisis that point to that territory, there a life that runs daily and there is also money in circulation, in this sense, even in the "sea of poverty" that the commom place present to our eyes, there are signs of high income occupied by the owner of the means of production, and external agents (diplomats, embassadors, NGO's representatives, and others of global reach). One of the most known is the district, highest and most distant from the port, "Petion Ville", a segregated enclave with hotels and supermarkets made to a high income public in the "heart"of the Haitian capital .

It is an urban landscape that communicate itself presenting, in of the poorest country of the world, the material production and a daily routine of few riches, some less poor and the poorest. 
Around $80 \%$ of the population is under poor conditions of living and a good amount of them are under extreme misery, depending on the assistencialist actions to survive.

David Harvey allerts to the restriction that the space can creat to the reproduction of the capital, this geographer wrote that

there is, I believe a much better way to think on the construction of crises. The analysis of the capital circulation points out to the very limits and the potential barriers. The lack of the money-capital, the labour problems, the disporpotionalities among the sectors, the natural limits, the organizational unbalanced technological changes (including the competition versus the monopoly), the indiscipline in the process of working and in the lack of effective demand are on the top of the list. (HARVEY, 2011, P.99).

Even observing many elements of those that Harvey indicates as present in the urban space in Port Prince, the logic of the capitalism impose itself in the space of exception and manages to reproduce in the poverty gathering crumbs and establishing in its dis(order) in the unequal sociospatial stratification that produces and reproduce.

Thinking in this way, the haitian space is a fruitful field for the strategy of reproduction of the activities linked to the capital, even that it is produced in other territories. The NGOs actions, the shippment of donations of haitians immigrants and the own role of the world networks of drugs trading, are examples of money and goods flows that territorialize in Haiti, fundamentally due to its immersion of several orders of crises.

As example, althought the numbers are imprecise, the records of "escape" of haitians looking for better life conditions in Brazil, Canadá, United States and, mainly in the neighbor Dominican Republic, are revealing on the true community of immigrants that, through shipment of resources, keep alive the bonds with the country of origin.

It is difficult to precise values, but the huge escape from the poorest Caribbean country has just turned into an importan source of resources for Haiti and send cheap and subservient workforce in the receiving countries. Harvey, when leading with the effects in global scale of the world crisis, approach this theme when writes that

Mexico, Ecuador, Haiti and Kerala, in India, that strongly depended on the sending of labour force from other places, all of a sudden saw their familiar incomes drying as far as the jobs in the construction industry abroad were lost and the house servant fired. Malnutritrion and death by hunger contradicting the idea that the marginalized population are not somehow affected by financial crises in the advanced capitalist world [...] The surplas population are not anchored in a place, as well as is not the capital. Thet flow to all places searching for opportunities or jobs, despite the barriers to immigration sometimes imposed by the Nation-states. [...] The Malnutrition and the hunger devast Haiti as far as the money sent from the USA dries because the house servants in New York and in Florida are loosing their job. (HARVEY, 2011, p.39, 122 e.123).

Another element, that has a humanitarian side, but that keeps some bait in its inside are the NGOs actions and the international contributions. On this theme there are some variables that deserve to be mentioned:

. Humanitarian aid is fundamental to the reproduction of life in Haiti, especially after the natural catástrofes (hurricaines and earthquakes). Haiti does not refuse this assistentialist aid in this acute phase of the crisis, and MINUSTAH notice, with concernings, that the contribution has declined due to the international economics crisis. It is importante to highlight that UN do not act in the economics development and only coordinate the agencies and organizations by means of clusters linked to OCHA (Office for the Coordination of Humanitarian Affairs). In a manner that the withdraw of the peace force does not mean the lack of that coordination for more some years in Hait. 
- Between the arrival of resources and the distribution to the population that needs it, there is a political gap that allows to think on the embezzlement, corruption and illegal beneficiation of the favoured groups. This difficulty of the state representation, even if it has been elected legitimately, it seems something obvious in Haiti. Donadio and Rial (2013, p.147) comment that far from the development plan and the interventions, it is necessary a government able to execute control and the projects consecution.

Considering the corruption as something real, many countries and institutions direct resources throught NGOs, visualizing in this sense a possibility to reach real humanitarian goals. This State under corruption suspicious and favours is added to a Normaded State that Santos (2005) had already announced .

. Other side of the analysis takes into consideration the organizations sustainability and jobs in countries under the label of humanitarian aid, including, under the bases of the crisis landmark, it is used the image of Haiti to get resources and stimulate the "humanitarian touristm".

Besides MINUSTAH that representes a number of UN workers present in Haiti, there are a huge number of NGOs, since the biggest ones such as OXFAM, Mediciéns sin frontiers and "Viva Rio", also a meaningful number of small ones with actions that vary from educational guidance (dancing, "capoeira", environmental education) to medical support in displacement areas after the earthquake.

The intention here is not to demonize the fundamental humanitarian aid that those organizations offer to the sensible areas, as the example of the poorest urban space of Port Prince, but configuring the list of the NGOs that act there, there is, certainly oportunism in a space of few legal rules and completely involved in the capital world in which the repercussions of economics order when sending and supporting these organizations from their nuclei in their base countries, opens huge possibilities to change the intentions and bad uses.

. The last consideration is related to the usual comment that is made in analyses on the assistencial support: the dependence that it is linked to those actions and the inercia that comes from the supported population. What is the real role of those assistencial policies? In which measure they must remain in the suported spaces? Those are hard issues to be questioned, and as oriente Souza (2006, p.299), the "resolution" of immediate problem (hunger, housing, education, sanitation, the building of peace, and soo $\mathrm{n}$ ), even considering essential, is not enough to a citzen and autonomous insertion. Those actions, as alerted by Donadio and Rial (2013, p.150), some times do not take into consideration the especificities of the banal space, since the ones who are in charge "come with their ideas and agendas and do not know the micro cosmos of the real local poverty and its reactions".

In other words, it is necessary to relates the humanitarian actions that are present in Haiti, especially in its capital, Port Prince, since, beyond the great proposal of assistance to the ones in need, there is a number of nuances between the donation, implanting and relations that are established within the organisms and the donators institutions and the receptors groups, besides that, imersed in the ceticismo of the capital, we come to Harvey $(2011$, p.122) to remember that "even in the selfconstruction housing in the slums, the waved iron, the boxes and the covers were first produced as goods".

\section{FINAL CONSIDERATIONS}

Thinking on urbanization on space of crisis, notably in the emphirical reality of Haiti, is to face itself in many tentacles and analytical possibilities, is lead with the banal space far from the crisis 
of the comteporaneous urbanization, especially (but not only) of linked to the peripheral world. In the case of Haiti, the "World slum" (DAVIS, 2006) reveals itself in all its brutality and, however, it is exactly this space of severe exclusion and restriction of minimum conditions of citizenship that the capital gets to reproduce itself revealing all the perversity of the global financing .

It is reflected in the daily a multiplicity of situations that comes from the encounter between the "economical city"and the "social city" (SANTOS, 2005). In where those imposes itself on the other in the side of argumentative strategies supported in the discourses that treat of humanitarian aid, territorial material reconstruction, peacekeeping, combat (and exercise) of corruption and the illegal activities as a support to the narcotrafic network, among others.

In a dichotomical way is possible to think that formally, there is not absence of plans and good intensions/suggestions to the treat with the hatian crisis, notably with the crisis in the urban space of Port Prince, however the logic that moves the city, the relations of assimetric power between the agents of production of the space, generates a uniqual and conflictive result, with litlle hope of subversion.

It is necessary to make a base in the local perspective of facing of the problems, without the naive localism "as strategy of resistence against the capitalist globalization" (SOUZA, 2006, p. 577) and all the repercussions of the supralocals escales in the production of the haitian space, but thinking in strategies to change the (dis)order that is now with the internal forces.

As a tentative of conclusion, especulating on the spaces of hope and following Santos (2000) considerations when aligned the elements that he called "Popular period, it is possible to think in subersives alternatives to crisis from the urban poor people: they present ways to subvert the logical of the capital to survive (informality, transports and radio alternatives, bombagay Market, and so on) ways that, inclusive, takes place from the interdependence in the interpersonal relations, differing, a lot, from the medium class (almost inexistent in Haiti) and the high urban that is decisively coopted, mainly as preferential consumers, by the power of money.

Yi-Fu Tuan (2005, p.270) alerts that "the poors and the oppressed suffer almost always in silence; or, if they cried in pain, their cry was in part ignore dor not documented, if not followed by a desperated action". This impersonality and dehumanisation in relation to the terrible conditions of reproduction of life in a huge number of people indicates to the said strategies of subversion implanted by the own excluded, even if pressing the political agenda It is the space of the poors concentraded as never before in spaces of exclusions that Santos (2006) sees as a beginning of hope.

The dimension of the text of an article limits the deepening of the analyses to a topic of this importance, even more if we combine to the absence of precise and current statistics numbers besides the difficulty of the achievement of a direct research of space in focus. These slots to the text are not fundamentally problems to the accomplishment of this writing, more than that, encourages the thinking and the continuity of the research, first by the relevance of the topic, after, by the possibility of, from the readings done about the space of Port Prince and Haiti, see convergences and distancings with other spatial experiences which rebound, in a "glocalizada" perspective (SOUZA, 2006, p.573) the vectors of contemporary crises.

However, we insist in the urgency of thinking in the emperical reality of the excluded, above all, as in our case, in Haiti, since that the "scenary of fear"(TUAN, 2005) that astonishes the imaginary of the individual that see it at the distanc, is the space of living of thousand of haitians, that in their daily clashes, face the perversity of the present that results of asymmetrical games of power between the agentes that produce that space of exclusion, but also spaces of possibities of reproduction of the capital.

\section{BIBLIOGRAPHICAL REFERENCE}

ANDRADE, A. B. Novas variáveis para o trato do território na contemporaneidade. Revista Finisterra. v.XLV, 2010, p.157-170. 
ANDRADE, A. B.; BRANDÃO, P. R. B. Geografia de Salvador. 2a .ed. Salvador: EDUFBA, 2009.

DAVIS, M. Planeta Favela.São Paulo: Boitempo, 2006.

DONADÍO, M. R.; RIAL, J.. La sombra de la violencia. Mujeres y fuerzas de paz en Haití y el Congo: un análisis de género y seguridad desde la perspectiva Latinoamericana. Buenos Aires: RESDAL, 2013.

EAKIN, M. C. The History of Latin America. Collision of Cultures. New York: Palgrave Macmillan, 2007. HABERMAS, J. Mudança estrutural da esfera pública. Rio de Janeiro: Tempo Brasileiro, 1984.

HARVEY, D. O enigma do capital. Trad. João Alexandre Perchanski. São Paulo: Boitempo, 2011.

JAMES, C. 1. R. Os jacobinos negros. Trad. Afonso Teixeira Filho. São Paulo: Boitempo, 2010.

KOWARICK, L. A espoliação urbana. Rio de Janeiro: Paz e Terra, 1979.

LEFEBVRE, H. Espacio y Politica: El Direcho a la Ciudad II. Barcelona: Ed. Peninsula, 1979. [ 1 ${ }^{\text {a }}$ ed. 1972].

MARICATO, E. Brasil, Cidades: Alternativas para a crise urbana. Petrópolis: Vozes, 2001.

OLIVEIRA. F. Crítica à Razão Dualista. In: Crítica à Razão Dualista / O Onitorrinco. São Paulo: BoiTempo Editorial, 2003. [O texto da Crítica à Razão Dualista foi publicado originalmente em 1972].

ONU (Organização das Nações Unidas). Precisamos definir metas até 2016, diz chefe da Missão da ONU sobre retirada de tropas do Haiti .31 de maio de 2013. Artigo de Nigel Fisher. Disponível em: http://www. onu.org.br. Acesso em: 25jun2013.

ONU (Organização das Nações Unidas). MINUSTAH. Disponível em: http://www.onu.org.br. Acesso em: 23 mar2014.

PIERUCCI, A. F. Experiência urbana da diversidade: além do conflito de interesses, o conflito de valores. In: GONÇALVES, M. F; BRANDÃO, C. A; GALVÃO, A. C.(orgs.) Regiões e cidades, cidades nas regiões. O desafio urbano regional. São Paulo: UNESP, 2003, p. 37-56.

SANTOS. M. O Espaço Dividido. Rio de Janeiro: Francisco Alves, 1979. [ 1 a ed. 1970]

SANTOS, M. Por uma outra Globalização. Rio de Janeiro, São Paulo: Record, 2000.

SANTOS. M. A Urbanização Brasileira, 5.ed. São Paulo: EDUSP, 2005. [1ª ed. 1991_Hucitec]

SIMMEL, G. A metrópole e a vida mental. In: VELHO, O. G. (org.) O Fenômeno Urbano. Rio de Janeiro: Zahar, 1976, p. 11-25. [1. ed.1902]

SOUZA, M. L.de. A Prisão e a Ágora. Reflexões em torno da democratização do planejamento e da gestão das cidades. Rio de Janeiro: Bertrand Brasil, 2006.

TOPALOV, C. Os saberes sobre a cidade. Espaço \& Debates, nº 23. São Paulo: NERU, 1991, p. 28-38.

TUAN, Yi-fu. Paisagens do medo. Trad. Lívia de Oliveira. São Paulo: Editora UNESP, 2005.

WILliamS, E. E. From Colombus to Castro. The History of the Caribbean. New York: Vint. Books Ed., 1984.

Submitted 5 may 2016

Accepted 27 may 2016 